\title{
A Study Investigating Bacterial Colonization on Automated Teller Machines in Ibadan Metropolis, South-West Nigeria
}

\section{Adedeji Bolutife Adedoyin*}

Department of Pharmaceutical Microbiology, Faculty of Pharmacy, University of Ibadan, Nigeria

*Corresponding Author: Adedeji Bolutife Adedoyin, Department of Pharmaceutical Microbiology, Faculty of Pharmacy, University of Ibadan, Nigeria.

Received: March 05, 2019; Published: May 17, 2019

DOI: $10.31080 /$ ASPS.2019.03.0286

\begin{abstract}
Different people from different socio-economic levels and hygiene status use the Automatic Teller Machines (ATM) daily and increase the chances of hand-borne transmission of microorganisms to the machine's surfaces. ATMs might be potential areas for pathogen accumulation and they might have a role in microbial transmission to the community.

This is a cross sectional analytical study using an average of ten (10) automated teller machines per local governments in seven (7) local government areas. Sterile cotton swabs soaked in physiological saline was used to take swabs from the keypad and screens of the ATM. The swabs were then cut into bacteriological peptone water for 24 hours and the inoculum from the peptone water streaked on different selective media including Cetrimide nutrient agar, mannitol salt agar, macconkey agar, Eosin methylene blue agar and blood agar. The inoculated media were then incubated for 24-48 hours. Standard biochemical tests were used to confirm the bacterial isolates.
\end{abstract}

The prevalence of bacteria found on the ATMs were Staphylococcus aureus 43 (51.8\%), Lactose fermenters 33 (39.7\%), Streptococcus spp. 19 (22.0\%), Pseudomonas spp. 17 (20.5\%), and Coagulase negative Staphylococcus spp 9 (10.8\%) respectively.

Antibiogram of the isolates showed the organisms to be most sensitive to imipenem and mainly resistant to ceftazidime.

Keywords: Staphylococcus aureus; Streptococcus; Pseudomonas; ATM

\section{Introduction}

\section{Automated teller machines}

The Automated Teller Machine (ATM) is a self-service machine that dispenses cash and performs some human teller functions like balance enquiry, bills payment, mini statements and so on. ATM transactions are carried out through the use of debit/credit cards which enable the card holders to access and carry out banking transactions without a teller.

Different people from different socio-economic levels and hygienic status use the ATMs daily and increase the chances of handborne transmission of microorganisms to the machine's surfaces. One of the most important routes for the spread of many infectious agents in the community is hand-borne transmission [1]. Hand transmission is a critical factor in the spread of bacteria, pathogens, viruses causing disease (Melissa Kaplan's Herp care collection, January 1, 2014).

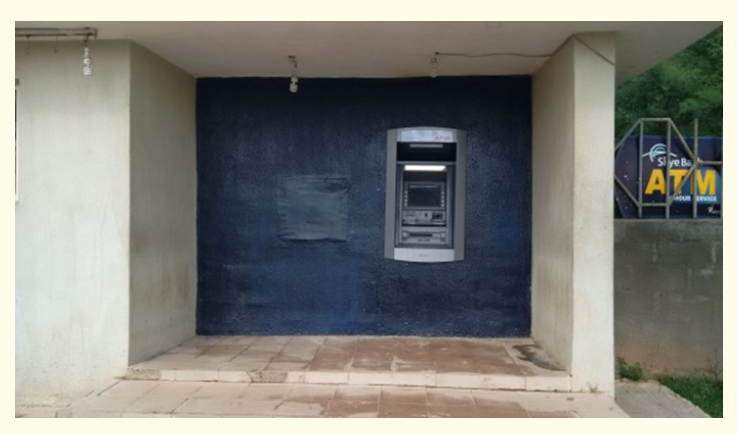

Figure a

\section{Microorganisms}

Microorganisms are forms of life that require magnification to see and resolve their structure. They include bacteria, yeasts, moulds, protozoa, algae, and rickettsia. Viruses are also included, 
although they cannot live or reproduce on their own. These cells may require magnification to be seen but when cultured on solid media that allow their growth and multiplication; they form visible colonies consisting of millions of cells. Microorganisms may be beneficial or disease causing (pathogenic) and need to be controlled in both cases. Microorganisms are everywhere in the environment, in high populations in soil, in the air we breathe, the water we drink, the food we eat, on our skin, in our noses, throats, mouths, intestinal cavities. (Web encyclopedia accessed 01/08/2016).

\section{Hand transmission of microorganisms}

Microorganisms recovered from hands can be divided into two categories namely: resident and transient. The resident flora consists of microorganisms residing under the superficial cells of the stratum corneum and can also be found on the surface of the skin. Resident flora is less likely to be associated with infections. Transient flora colonizes superficial layers of the skin and is more amenable to removal by routine hand hygiene (Price, 1938). Transient flora can move from hand to hand or hand to surfaces by contact with the hands or surfaces. Hand transmission is a critical factor in the spread of bacteria, pathogens, viruses causing disease, food borne illness and nosocomial infections. It has also been shown that microbes once attached to hands and to some surfaces may survive for a while and be difficult to remove.

\section{Microbial colonization of surfaces}

Microbes are found on surfaces that require contact with human hands e.g. computer keyboards, door handles, mobile phones, elevator buttons. Objects and social devices serve as microbial reservoirs.Many factors have been shown to influence the bacterial transfers between surfaces, including the source and destination surface features, bacterial species involved, moisture levels, pressure and friction between the contact surfaces, and inoculum size on surfaces [2]. Many bacterial, fungal and viral pathogens could survive on inanimate objects for several months, and such pathogens could cause epidemic infections (Kramer., et al. 2006). Many epidemiological studies have confirmed that many contaminated surfaces played a major role in the spread of infectious diseases.

\section{Microbial colonization of automated teller machines (ATMS)}

Different people from different socio-economic levels and hygienic status use the ATMs daily and increase the chances of handborne transmission of microorganisms to the machine's surfaces. Studies have shown that there is heavy contamination of the parts of ATMs that have contact with customers' hands such as the keypads and screens. ATMs might be potential areas for pathogen ac- cumulation and they might have a role in microbial transmission in the community [1].

\section{Aim and Objectives}

The major aim of this study was to estimate the prevalence of bacterial colonization on Automated Teller Machines (ATMs) in Ibadan, South-West Nigeria.

The specific objectives of this study were:

- $\quad$ To characterize bacteria found on Automated teller Machines (ATMs) in Ibadan, South-West Nigeria

- To quantify the bacteria found on ATMs in Ibadan

- To determine the antimicrobial susceptibility profile of the isolates.

- To test the efficacy of some commercially available disin fectants on the isolates.

- The hypotheses for this study are as follow:

- The Automated Teller Machines will have a high bacterial load.

- $\quad$ The isolates will be susceptible to most antibiotics.

- The efficacy of commercially available disinfectants on the isolates will be desired.

\section{Literature Review}

Bacterial colonization of surfaces

Oxford dictionary defines colonization as the action by a plant or animal establishing itself in an area. Microbes are found on surfaces that require contact with human hands e.g. computer keyboards, door handles, mobile phones, elevator buttons. Objects and social devices serve as microbial reservoirs.

Many epidemiological studies have confirmed that many contaminated surfaces played a major role in the spread of infectious diseases [1-3]. Many bacterial, fungal and viral pathogens could survive on the inanimate objects for several months, and such pathogens cold cause epidemic infections as a result of direct or indirect transmission in 'hand-object-susceptible patient ring' [2]. Other studies by Tekekoglu., et al. [1] and Dogan., et al. [4] reported that multi-drug resistant hospital pathogens were carried on cell phones of patients, visitors and health care workers.

Commonly found bacteria on automated teller machine (ATM) surfaces

Several research groups have conducted studies on microbiological surveillance of Automated Teller Machines (ATMs) and reported the presence of different types of bacteria. 
Tekerekoglu., et al. [1] reported finding Bacillus spp, Coagulase negative Staphylococcus (CoNS) methicillin resistant and methicillin susceptible, Staphylococcus aureus both methicillin resistant and susceptible, Escherichia coli while Nagajothi., et al. [2] reported finding Klebsiella, Pseudomonas aeruginosa, Escherichia coli, Staphylococcus aureus, Enterobacter, Acinetobacter spp, Coagulase negative Staphylococcus and Non fermenters on ATMs in two different studies in Turkey and India, respectively.

\section{Bacillus Spp}

Bacillus is a genus of gram-positive, rod-shaped bacteria of the phylum Firmicutes. Bacillus species can be obligate aerobes or facultative aerobes and will test positive for the enzyme catalase when there has been oxygen used or present (Baron's medical microbiology 1996). Bacillus are ubiquitous in nature and include both freeliving and parasitic pathogenic species [5]. Under stressful environmental conditions, the bacteria can produce endospores to which the bacteria can reduce themselves and remain in a dormant state for very long periods [5].

Bacillus subtilis is an important model organism that is also notable as a food spoiler causing ropiness in bread as well as related food. Some environmental and commercial strains of Bacillus coagulans may play a role in food-spoilage of highly acidic, tomatobased product. Two Bacillus species considered medically significant are Bacillus anthracis which causes anthrax and Bacillus cereus which causes food poisoning.

\section{Coagulase-negative Staphylococcus}

Coagulase-negative Staphylococcus are a subdivision of Staphylococci that do not produce coagulase. They are gram-positive, occur singly and in irregular grape-like clusters. (Gram positive pathogens ASM press Washington DC).

Coagulase-negative staphylococci (CoNS) are part of the normal flora of the human skin. They have relatively low virulence but are increasingly recognized as agents of clinically significant infection of the blood stream and other sites [6]. Coagulase-negative staphylococci are frequently associated with nosocomial infections, $41 \%$ of the time when bacteremia is present, and of this many are line infections. Coagulase-negative staphylococci may be methicillin susceptible or resistant.

\section{Staphylococcus aureus}

Staphylococcus aureus is a gram-positive coccal bacterium that is a member of the Firmicutes and is frequently found in the nose, respiratory tract and on the skin. It is often positive for catalase and nitrate reduction. Staphylococcus aureus is not always pathogenic, however it is a common cause of skin infections, respiratory infections and food poisoning. Pathogenic strains often promote infections by producing potent protein toxins and expressing cell surface proteins that bind and inactivate antibodies. A worldwide problem in clinical medicine is the emergence of antibiotic resistant strains of Staphylococcus aureus such as methicillin-resistant Staphylococcus aureus (MRSA).

\section{Escherichia coli}

Escherichia coli is a gram-negative, facultatively anaerobic, rodshaped bacterium of the genus Escherichia that is commonly found in the lower intestine of warm-blooded organisms [7]. Most Escherichia coli strains are harmless but some serotypes can cause serious poisoning in their hosts. Virulent strains of Escherichia coli can cause gastroenteritis, urinary tract infections and neonatal meningitis.

\section{Antibiotics}

The term 'antibiotic' is most appropriately defined as "a chemical compound derived from or produced by a living organism or semi-synthesized or produced as a synthetic small analogue of naturally occurring compound, which is capable in small concentrations, of inhibiting the life processes of microorganisms (bacteria, mycobacteria, fungi, amoebae)" [8].

Antibiotics are commonly classified based on their mechanism of action, chemical structure or spectrum of activity. Based on mechanism of action, antibiotics may be classified into; those that target bacterial cell wall (Penicillins and Cephalosporins), those that target cell membranes (Polymyxins), those that interfere with essential bacterial enzymes (Rifampicins, Quinolones and Sulphonamides ), those that target protein synthesis (Macrolides, Lincosamides and Tetracyclines) (Brunton., et al. 2007).

Based on chemical structure, antibiotics may be classified into; Penicilins (e.g. Ampicillin, Amoxicillin), Cephalosporins (e.g. Cefuroxime, Cephalexin), Macrolides (e.g. Erythromycin, Azithromycin), Fluoroquinolones (e.g. Ciprofloxacin, Ofloxacin), Sulphonamides (e.g. Sulphadoxine, Sulphamethoxazole), Tetracyclines (e.g. Tetracycline, Doxycycline), Aminoglycoside (e.g. Gentamycin, Streptomycin) [8]. Based on spectrum of activity, antibiotics may also be classified as narrow-spectrum or broad-spectrum antibiotics [8].

\section{Disinfectants}

The term 'disinfectant' is traditionally used for chemical agents employed to destroy microorganisms on inanimate objects. A dis- 
infectant does not necessarily kill all microorganisms but it reduces them to a level which is not harmful to health. The process of using chemical disinfectants in inhibiting or killing pathogenic microorganisms is known as disinfection [9]. Frequent disinfection limits bacterial transmission and accumulation on surfaces [1]. There are various classes of chemical disinfectants; Acids and their esters (e.g. acetic acid, benzoic acid), Alcohols (e.g. ethanol, isopropanol),Aldehydes(e.g. glutaraldehyde, formaldehyde), Alkali(e.g. sodium hydroxide, sodium carbonate), Biguanides (e.g. chlorhexidine), Diamidines(e.g. propamidne), Halogens (e.g. chlorine, iodine),Heavy Metals (e.g. mercury, silver), Oxidizing agents (e.g. hydrogen peroxide, peracetic acids),Phenols (e.g. phenol, chlorinated phenols),Surface Active agents (e.g. benzalkonium chloride, cetrimide) [9].

\section{Methodology \\ Materials}

The materials used for the sample collection and laboratory investigation included Sterile cotton swab, Petri dishes, Incubator, Autoclave, Normal saline, Scissors, Bacteriologic peptone water.

\section{Equipment and glasswares}

Some of the equipment used during this study includes; Measuring cylinder (Techincal),Test tubes (pyrex), Conical flasks (pyrex), Spatula, Glass beakers (uniscope), Petri - dishes (sliver Health Diagnosis), Wire loop, Autoclaves (Health Quip medical prooducts), Incubator (Gallenkamp), Weighing balance (Amput Electronic scale), Weighing boat, Sterile drying oven(GallenKamp), Universal bottles, Bunsen burner Griffin and George ltd), Glass slides, Microscope (Olympus), Forceps and Pipettes (Pyrex).

\section{Culture media}

The culture media used includes Nutrient Agar (LABM), Eosine methylene Blue (EMB) Agar (LABM), Mueller Hinton Agar (Rapid Lab), Cetrimide Nutrient Agar, MacConkey Agar (LabM).

Details of the composition and preparation of the media are presented in Appendix 1

\section{Standard antibiotics discs}

The following standard single discs (Oxoid® UK) were used: Imipenem (IPM - 10ug), Amoxicillin/clavulanic (AMC - 30ug), Chloramphenicol (C - 15ug), Erythromycin (E - 15ug), Nitrofurantoin ( F - 300ug), Sulphamethoxazole/ trimethoprim (SXT 25ug), Gentimicin (GN - 30ug), Ofloxacin (OFX - 5ug), Tetracycline (TE 30ug), Ceftazidine (CAZ - 10ug), Cefotaxime (CTX - 30ug), Vancomycin (VA - 30ug).

\section{Study design}

This is a cross-sectional analytical study with sample collection conducted between May and August 2016 in the seven (7) Local Government Areas in Ibadan, South-West Nigeria which has an estimated population of over 3.5 million people. The laboratory investigations were conducted between May and October 2016 in the Pharmaceutical Microbiology laboratory, Faculty of Pharmacy, University of Ibadan.

\section{Study sites}

The seven Local Government Areas (LGAs) in Ibadan Metropolis were Akinyele, Ibadan North, Ibadan North East, Ibadan North West, Ibadan South East, Ibadan South West and Oluyole local government areas.

\section{Sample size}

Eighty three ATMs i.e. an average of twelve (12) different ATMs from each of the seven (7) Local Government Areas (LGA). Purposive sampling methodology was used to select six banks from each LGA and samples were collected from the ATMs.

The total sample size for this study was 83 and the error margin for the study was determined to be $\pm 0.05 \%$ using the formula stated below;

\section{$\mathrm{N}=[\mathrm{Z} \alpha / 2 \times \sigma] 2 / \mathrm{E}$}

Where $N$ is sample size; $Z \alpha / 2$ is value of normal variables at $\alpha$ level of significance; $\mathrm{E}$ is error margin allowable and $\sigma$ is the standard deviation in the population.

Note that Range $=4 \sigma$; thus $\sigma=0.25$ and $Z \alpha / 2$ at $95 \%$ level of confidence is 1.96

\section{Inclusion criteria}

All Automated Teller Machines (ATMs) outside the selected banking halls were included in the study

\section{Exclusion criteria}

All Automated Teller Machines not within bank premises were excluded from the study.

\section{Method}

\section{Collection of bacteria isolates}

Written permission were obtained from seventeen (17) banking organizations including Zenith, United Bank of Africa, Skye, First Bank of Nigeria, Access Bank and Stanbic Bank. Samples were collected from the key-pads and screens of the ATM devices outside banking halls with sterile cotton swabs soaked in physiologic saline. About one hundred and ten (110) isolates were obtained from different automated teller machine (ATM) with sterile swab 
sticks and sterile normal saline. They were isolated and screened by Gram staining, culture methods using Cetrimide Nutrient Agar (CNA), Mannitol Salt Agar (MSA), MacConkey and Eosin Methylene blue Agar (EMB) and incubated for 24 hours at $37^{\circ} \mathrm{C}$.

The microorganisms were confirmed by conventional biochemical test such as catalase, indole, oxidase. Pure cultures of the bacterial isolate were inoculated on fresh nutrient agar slants and stored in the refrigerator at $4^{\circ} \mathrm{C}$. The bacterial isolate gotten were Pseudomonas aeruginosa, Staphylococcus aureus, and Streptococcus.

\section{Characterization of collected isolates}

Isolates were streaked on specific medium according to the genus to which the bacteria belong. Enterobacteriaceae (Escherichia coli, Klebsiella spp., and Enterobacter spp.) were streaked on MacConkey and Eosin methylene Blue (EMB) agar, Pseudomonas aeruginosa was streaked on Cetrimide agar while Staphylococcus aureus was streaked on Mannitol Salt agar (MSA). The culture plates were incubated at $37^{\circ} \mathrm{C}$ for 24 hours in an incubator. Cultural characteristics and morphologies of the colonies were then observed and identity recorded.

\section{Gram staining}

For each bacterial isolate, a tiny speck of the colony (obtained from an overnight culture of the organism on nutrient agar) was placed on a grease-free slide with the aid of sterile inoculating loop. The smear was allowed to dry completely in the air and fixed by passing rapidly through the flame. It was stained with few drop of crystal violet for 30 seconds and washed off with sterile distilled water. Staining was done with iodine solution as a mordent for one minute. The iodine was washed off and rinsed with distilled water. The smear was decolorized with alcohol until no violet colour was seen. The excess alcohol was drained off and slide was covered with $1 \%$ safranin for 30 seconds before rinsing off with distilled water. The smear was allowed to dry in the air and immersion oil was added. The slide was mounted on the microscope stage and viewed.

\section{Biochemical tests}

About two drops of 3\% hydrogen peroxide (H2O2) reagent graded was placed on clean microscope slide. A tiny speck of bacterial colony (obtained from overnight culture of the organisms on nutrient agar) of the test organism was taken and rubbed in hydrogen peroxide using sterile inoculating loop. Immediate production of bubbles indicates the present of catalase enzyme in the isolate. This latest determiners the ability of the organisms to produce catalase enzymes.

\section{Indole test}

A small speck of bacteria of bacteria colony from an overnight culture was inoculated into a tube of peptone water and incubated for 48 hours at $37^{\circ} \mathrm{C}$. Thereafter, few drops of Kovac's reagent were added to the culture with gentle shaking. A red ring in the surface layer of the culture within 1 minute showed a positive result for $E$. coli.

\section{Oxidase test}

A speck of colony from overnight culture of test organism was smeared on a portion of the oxidase strip (Oxoid ${ }^{\circledR} \mathrm{UK}$ ) using a glass rod. A dark purple coloration with 5 - 10 seconds indicates a positive result. This test was used to identify Pseudomonas aeruginosa which produces the cytochrome oxidase enzymes.

\section{Antimicrobial susceptibility test}

Sensitivity Testing of the bacterial to antibiotics

Bacterial colony from overnight culture was suspended in bottle containing $10 \mathrm{ml}$ of sterile distilled water at $0.5 \mathrm{Mcfarland}$ standard. A bacterial suspension of $0.2 \mathrm{~mL}$ seeded into 20 millitres of melted and cooled Mueller-Hinton agar was poured into sterile petri-dish and allow to set. The antibiotics discs (3.1.3 above) were placed at equal distance on the surface of the inoculated sterile plate using a sterile forceps. The plates were incubated invertedly at 370C for 24 hours. The zones of inhibition around the antibiotics discs were measured in mm with ruler and recorded.

\section{Sensitivity testing of the bacteria to disinfectants}

The agar diffusion method was used (Alabi and Sanusi, 2012). A $0.2 \mathrm{ml}$ of bacteria suspension was seeded into $20 \mathrm{~mL}$ of molten and cooled agar, then poured into sterile petri dishes and allowed to set. Four (4) holes were bored with the aid of 8mm cork borer. The four holes/wells were filled with disinfectants (Manufacturer's in-use concentration of Dettol(R), Savlon(R), and Jik(R)). Sterile distilled water and Gentamicin discs (Oxoid ${ }^{\circledR} \mathrm{UK}$ ) were used as negative and positive controls, respectively. The petri dishes were left for 45 minutes to diffuse, and incubated at $37^{\circ} \mathrm{C}$ for 24 hours. The zones of inhibition were measured and recorded.

\section{Data analysis}

Microsoft Excel (Windows 8) was used to collate and analyse the data. Descriptive statistics was used in summarizing the data.

\section{Results}

General

A total of one hundred and ten swabs were taken from keypads and screens of ATM from the seven Local Government Areas (LGAs) in Ibadan metropolis. A summary of the Local Governments, banks and ATMs are shown in Table 1. Majority of the ATMs belong to First Bank of Nigeria while banks such as Heritage and Sterling had only one ATM represented in all the local governments visited. Table 2 shows a summary of prevalence of microorganisms present on the ATMs with Staphylococcus aureus being the most common and coagulase-negative Staphylococcus (CoNS) being the least. 


\begin{tabular}{|c|c|c|c|c|c|}
\hline LOCAL GOVERNMENT & BANK NAME & CODE & \multirow[t]{11}{*}{ OLUYOLE } & FBN & D1 \\
\hline \multirow[t]{10}{*}{ AKINYELE } & ACCESS & $\mathrm{A} 1$ & & FBN & D2 \\
\hline & ECOBANK & $\mathrm{A} 2$ & & GTR & $\mathrm{D3}$ \\
\hline & FCMB & A3 & & UID & DJ \\
\hline & FCMB & A4 & & FCMB & D4 \\
\hline & FCMB & A5 & & STANBIC & D5 \\
\hline & FCMB & A6 & & STANDARD CHA & D6 \\
\hline & FCMB & A7 & & ACCESS & D7 \\
\hline & ACCESS & A8 & & ACCESS & D8 \\
\hline & ACCESS & A9 & & DIAMOND & D9 \\
\hline & FBN & A10 & & FIDELITY & D10 \\
\hline \multirow[t]{10}{*}{ IBADAN SOUTH WEST } & GTB & B1 & \multirow[t]{4}{*}{ IBADAN NORTH WEST } & UNION & E1 \\
\hline & GTB & $\mathrm{B} 2$ & & WEMA & E2 \\
\hline & FBN & B3 & & WEMA & E3 \\
\hline & FBN & B4 & & WEMA & E4 \\
\hline & FBN & B5 & \multirow[t]{6}{*}{ IBADAN NORTH WEST } & FBN & E5 \\
\hline & FBN & B6 & & HERITAGE & E6 \\
\hline & ACCESS & B7 & & STERLING & E7 \\
\hline & ACCESS & B8 & & UBA & E8 \\
\hline & ZENITH & B9 & & ACCESS & E9 \\
\hline & ZENITH & B10 & & SKYE & E10 \\
\hline \multirow[t]{21}{*}{ IBADAN NORTH } & SKYE & $\mathrm{C} 1$ & \multirow[t]{11}{*}{ IBADAN NORTH EAST } & ZENITH & F1 \\
\hline & SKYE & $\mathrm{C} 2$ & & ZENITH & $\mathrm{F} 2$ \\
\hline & SKYE & $\mathrm{C} 3$ & & ZENITH & F3 \\
\hline & FCMB & $\mathrm{C} 4$ & & UBA & $\mathrm{F} 4$ \\
\hline & FCMB & C5 & & UBA & F5 \\
\hline & ACCESS & C6 & & UNION & F6 \\
\hline & SKYE & $\mathrm{C} 7$ & & UNION & F7 \\
\hline & FBN & C8 & & ACCESS & F8 \\
\hline & FBN & C9 & & & \\
\hline & FBN & $\mathrm{C} 10$ & & ACCESS & F9 \\
\hline & ACCESS & H1 & & UNITY & F10 \\
\hline & ACCESS & $\mathrm{H} 2$ & \multirow[t]{10}{*}{ IBADAN SOUTH EAST } & FCMB & G1 \\
\hline & FBN & H3 & & FCMB & G2 \\
\hline & FBN & $\mathrm{H} 4$ & & ACCESS & G3 \\
\hline & FCMB & $\mathrm{H} 5$ & & ACCESS & G4 \\
\hline & & NL1 & & SKYE & G5 \\
\hline & & NL2 & & SKYE & G6 \\
\hline & & NL3 & & FBN & G7 \\
\hline & & NL4 & & FBN & G8 \\
\hline & & NL5 & & FBN & G9 \\
\hline & & NL6 & & ZENITH & G10 \\
\hline
\end{tabular}

Table 1: Summary of local governments and banks visited. 


\begin{tabular}{|l|c|c|c|}
\hline S/N & NAME & $\begin{array}{c}\text { Number of ATM } \\
\text { from which } \\
\text { organism was } \\
\text { obtained }\end{array}$ & \% Frequency \\
\hline 1 & S. aureus & 43 & 51.8 \\
\hline 2 & $\begin{array}{c}\text { Coagulase-negative } \\
\text { Staphylococcus } \\
\text { (CoNS) }\end{array}$ & 9 & 10.8 \\
\hline 3 & Pseudomonas spp & 17 & 20.5 \\
\hline 4 & $\begin{array}{c}\text { E. coli Lactose } \\
\text { Fermenter }\end{array}$ & 33 & 39.8 \\
\hline 5 & Streptococcus $\mathrm{spp}$ & 19 & 22.9 \\
\hline
\end{tabular}

Table 2: Summary of bacteria found on the eighty three ATMs and their prevalence.

Authentication of bacterial isolate

Fifty (50) isolates were randomly selected 10 each of $S$. aureus, E. coli, Pseudomonas spp, Streptococcus spp, and Proteus spp) from the 83 isolates obtained from the ATM swabs. These were subjected to gram staining and standard biochemical tests.

Table 3 shows the summary of the biochemical tests. Isolates found to be Gram-negative rods, Catalase positive and showed greenish metallic sheen on EMB agar were identified as E. coli; while Gram negative rods that were oxidase positive and grew on Cetrimide agar were identified as Pseudomonas aeruginosa. Gram negative rods that were swarming on MacConckey agar and had fishy smell, catalase positive, indole negative were identified as Proteus spp. Yellow colonies that fermented on Manitol Salt Agar were suspected to be $S$. aureus (Figure 1). The presence of S. aureus was also confirmed with evolution of bubbles from hydrogen peroxide while heamolysis of blood on Blood agar confirmed Streptococcus spp (Figure 2).

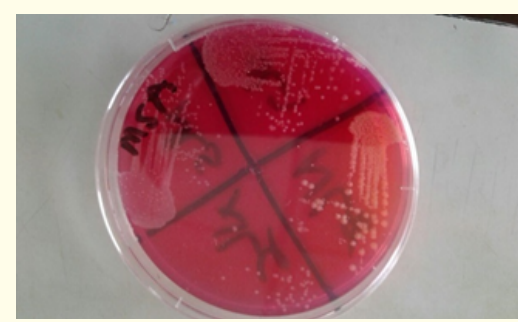

Figure 1: Staph aureus obtained from using Mannitol Salt Agar.
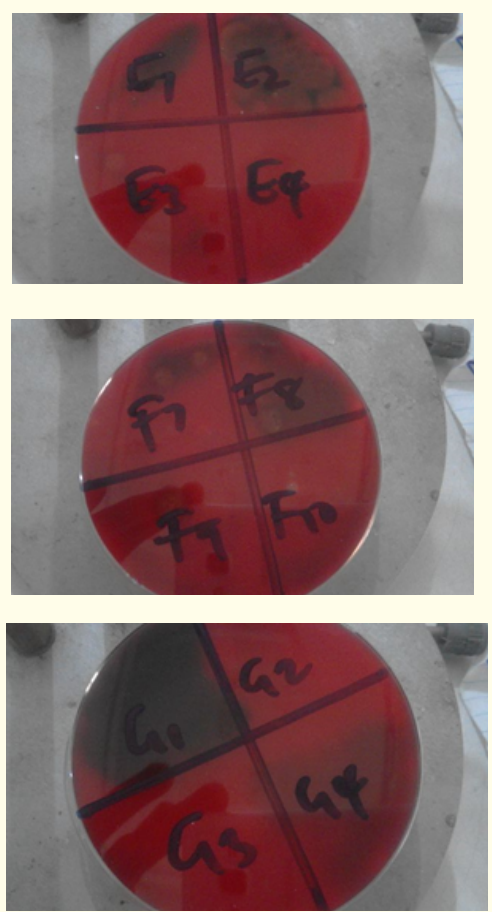

Figure 2: Streptococcus spp isolated on Blood Agar.

\begin{tabular}{|l|c|c|c|c|c|}
\hline Biochemical Test & E. coli & S. aureus & Pseudomonas spp & Proteus spp & Streptococcus spp \\
\hline Catalase & + & + & + & ND & ND \\
\hline Indole & + & - & - & ND & ND \\
\hline Oxidase & - & + & ND & ND & ND \\
\hline EMB agar & Green metallic & ND & ND & ND & ND \\
\hline MacConkey & ND & ND & ND & Swarming & ND \\
\hline Cetrimide & NG & NG & Greenish & NG & NG \\
\hline
\end{tabular}

Table 3: Confirmatory biochemical tests identifying the isolates.

\section{KEY}

+: Positive

- : Negative

ND: Not Determined

NG: No Growth 
Antibiotics Susceptibility pattern of bacteria Isolates

The antibiogram of 50 randomly selected isolates [E. coli (20\%), Pseudomonas spp, (20\%), S. aureus (20\%), Proteus spp (20\%) and Streptococcus spp (20\%) were determined using the Kirby-Baeur disc-diffusion technique and interpreted accordimg to the CLSI guideline. There were varying degree of sensitivity to the other antibiotics. The 50 bacterial isolates were all sensitive (at the recommended manufacturer's in-use concentration) to the commercially available disinfecatants Dettol, Savlon and Jik used in this study.

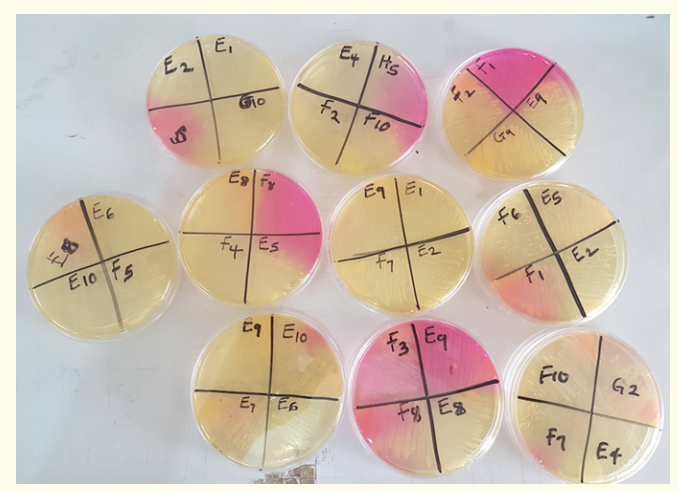

Figure 3: Pictorial representation of S. aureus collected from various ATMs.

\begin{tabular}{|l|c|c|c|}
\hline \multirow{2}{*}{$\begin{array}{c}\text { Antimicrobial } \\
\text { Agents }\end{array}$} & \multicolumn{3}{|c|}{ Zone of Inhibition in mm } \\
\cline { 2 - 4 } $\begin{array}{l}\text { Amoxicillin/ } \\
\text { Clavulanic acid }\end{array}$ & $\geq 18$ & $14-17$ & $\leq 13$ \\
\hline Amoxicillin & $\geq 17$ & $14-16$ & $\leq 13$ \\
\hline Cefotaxime & $\geq 26$ & $23-25$ & $\leq 22$ \\
\hline Ceftazidime & $\geq 21$ & $18-20$ & $\leq 17$ \\
\hline Ciprofloxacin & $\geq 21$ & $16-20$ & $\leq 15$ \\
\hline $\begin{array}{l}\text { Chlorampheni- } \\
\text { col }\end{array}$ & $\geq 18$ & $13-17$ & $\leq 12$ \\
\hline Erythromycin & $\geq 23$ & $14-22$ & $\leq 13$ \\
\hline Gentamicin & $\geq 15$ & $13-14$ & $\leq 12$ \\
\hline Meropenem & $\geq 23$ & $20-22$ & $\leq 19$ \\
\hline Nitrofurantoin & $\geq 17$ & $15-16$ & $\leq 14$ \\
\hline $\begin{array}{l}\text { Sulphamethox- } \\
\text { azole/ Trime- } \\
\text { toprim }\end{array}$ & $\geq 16$ & $11-15$ & $\leq 10$ \\
\hline Tetracycline & $\geq 15$ & $12-14$ & $\leq 11$ \\
\hline
\end{tabular}

Table 4: Interpretation of zones of inhibition according to Clinical and Laboratory Standards Institutes (CLSI 2012).

\begin{tabular}{|c|c|c|c|c|c|c|c|c|c|c|c|c|c|c|}
\hline \multicolumn{3}{|c|}{ Isolate ID } & \multicolumn{12}{|c|}{ Diameter zones of inhibition (MM) } \\
\hline \multirow[t]{11}{*}{ S. aureus } & $\mathbf{S} / \mathbf{N}$ & ID & VA & C & SXT & CAZ & IPM & GN & $\mathbf{F}$ & TE & CTX & AMC & OFX & $\mathbf{E}$ \\
\hline & 1 & E8 & 16 & 12 & $\mathrm{R}$ & $\mathrm{R}$ & 28 & 18 & 22 & $\mathrm{R}$ & $\mathrm{R}$ & 32 & 24 & 20 \\
\hline & 2 & G10 & 14 & 12 & $\mathrm{R}$ & $\mathrm{R}$ & 22 & 12 & 10 & $\mathrm{R}$ & $\mathrm{R}$ & 22 & 12 & 14 \\
\hline & 3 & E7 & 20 & 14 & $\mathrm{R}$ & $\mathrm{R}$ & 24 & 16 & 18 & 10 & $\mathrm{R}$ & 12 & 14 & 12 \\
\hline & 4 & G9 & 20 & 24 & $\mathrm{R}$ & $\mathrm{R}$ & 38 & 20 & 16 & 10 & $\mathrm{R}$ & 26 & 20 & 20 \\
\hline & 5 & F10 & 16 & 12 & $\mathrm{R}$ & $\mathrm{R}$ & 32 & 22 & 20 & $\mathrm{R}$ & 14 & 22 & 18 & 16 \\
\hline & 6 & $\mathrm{E} 2$ & 16 & 12 & $\mathrm{R}$ & $\mathrm{R}$ & 26 & 20 & 22 & $\mathrm{R}$ & 14 & 20 & 18 & 16 \\
\hline & 7 & E1 & 20 & 16 & 12 & $\mathrm{R}$ & 22 & 16 & 20 & $\mathrm{R}$ & 14 & 18 & 20 & 14 \\
\hline & 8 & $\mathrm{~F} 2$ & 18 & 12 & $\mathrm{R}$ & $\mathrm{R}$ & 30 & 24 & 16 & $\mathrm{R}$ & 14 & 12 & 14 & 20 \\
\hline & 9 & E9 & 18 & 14 & $\mathrm{R}$ & $\mathrm{R}$ & 32 & 20 & 14 & $\mathrm{R}$ & 14 & 20 & 20 & 20 \\
\hline & 10 & E5 & 20 & 10 & $\mathrm{R}$ & $\mathrm{R}$ & 32 & 16 & 20 & $\mathrm{R}$ & $\mathrm{R}$ & 16 & 18 & 18 \\
\hline \multirow{10}{*}{$\begin{array}{l}\text { Pseudomonas } \\
\text { aeruginosa }\end{array}$} & 1 & $\mathrm{~F} 4$ & $\mathrm{R}$ & $\mathrm{R}$ & 20 & $\mathrm{R}$ & 24 & 22 & 14 & $\mathrm{R}$ & 14 & $\mathrm{R}$ & 14 & 16 \\
\hline & 2 & D2 & $\mathrm{R}$ & 12 & $\mathrm{R}$ & $\mathrm{R}$ & 16 & 28 & $\mathrm{R}$ & $\mathrm{R}$ & $\mathrm{R}$ & $\mathrm{R}$ & 20 & $\mathrm{R}$ \\
\hline & 3 & A4 & $\mathrm{R}$ & 12 & $\mathrm{R}$ & $\mathrm{R}$ & 12 & 20 & $\mathrm{R}$ & $\mathrm{R}$ & $\mathrm{R}$ & $\mathrm{R}$ & 18 & $\mathrm{R}$ \\
\hline & 4 & D1 & $\mathrm{R}$ & $\mathrm{R}$ & $\mathrm{R}$ & $\mathrm{R}$ & 12 & 22 & $\mathrm{R}$ & $\mathrm{R}$ & $\mathrm{R}$ & - & 14 & $\mathrm{R}$ \\
\hline & 5 & B4 & $\mathrm{R}$ & $\mathrm{R}$ & $\mathrm{R}$ & $\mathrm{R}$ & 12 & 20 & $\mathrm{R}$ & $\mathrm{R}$ & $\mathrm{R}$ & $\mathrm{R}$ & $\mathrm{R}$ & $\mathrm{R}$ \\
\hline & 6 & E6 & $\mathrm{R}$ & $\mathrm{R}$ & $\mathrm{R}$ & $\mathrm{R}$ & 30 & 20 & $\mathrm{R}$ & $\mathrm{R}$ & $\mathrm{R}$ & $\mathrm{R}$ & 22 & $\mathrm{R}$ \\
\hline & 7 & $\mathrm{E} 4$ & $\mathrm{R}$ & $\mathrm{R}$ & 14 & $\mathrm{R}$ & 32 & 28 & $\mathrm{R}$ & $\mathrm{R}$ & $\mathrm{R}$ & $\mathrm{R}$ & 20 & $\mathrm{R}$ \\
\hline & 8 & A5 & $\mathrm{R}$ & $\mathrm{R}$ & $\mathrm{R}$ & $\mathrm{R}$ & 14 & 26 & $\mathrm{R}$ & $\mathrm{R}$ & $\mathrm{R}$ & $\mathrm{R}$ & 22 & $\mathrm{R}$ \\
\hline & 9 & C8 & $\mathrm{R}$ & 12 & $\mathrm{R}$ & $\mathrm{R}$ & 16 & 24 & $\mathrm{R}$ & $\mathrm{R}$ & $\mathrm{R}$ & $\mathrm{R}$ & 24 & $\mathrm{R}$ \\
\hline & 10 & D10 & $\mathrm{R}$ & 12 & $\mathrm{R}$ & $\mathrm{R}$ & 24 & 20 & $\mathrm{R}$ & $\mathrm{R}$ & $\mathrm{R}$ & $\mathrm{R}$ & 22 & $\mathrm{R}$ \\
\hline
\end{tabular}




\begin{tabular}{|c|c|c|c|c|c|c|c|c|c|c|c|c|c|c|}
\hline \multirow[t]{10}{*}{ Streptococcus } & 1 & E7 & 22 & 24 & 24 & $\mathrm{R}$ & 32 & 24 & 22 & $\mathrm{R}$ & $\mathrm{R}$ & $\mathrm{R}$ & 24 & $\mathrm{R}$ \\
\hline & 2 & H3 & 16 & 20 & 22 & $\mathrm{R}$ & 18 & 12 & $\mathrm{R}$ & $\mathrm{R}$ & $\mathrm{R}$ & 18 & 24 & 22 \\
\hline & 3 & $\mathrm{~F} 2$ & $\mathrm{R}$ & 16 & 20 & $\mathrm{R}$ & 24 & 14 & 18 & $\mathrm{R}$ & $\mathrm{R}$ & 22 & 12 & $\mathrm{R}$ \\
\hline & 4 & E7 & 20 & 14 & 24 & $\mathrm{R}$ & 26 & 24 & 10 & $\mathrm{R}$ & $\mathrm{R}$ & 28 & 16 & 18 \\
\hline & 5 & H5 & 20 & 22 & $\mathrm{R}$ & $\mathrm{R}$ & 24 & 20 & $\mathrm{R}$ & 12 & $\mathrm{R}$ & $\mathrm{R}$ & 28 & 20 \\
\hline & 6 & G1 & 16 & $\mathrm{R}$ & $\mathrm{R}$ & $\mathrm{R}$ & 28 & 22 & $\mathrm{R}$ & $\mathrm{R}$ & $\mathrm{R}$ & 20 & 18 & 16 \\
\hline & 7 & $\mathrm{~F} 1$ & $\mathrm{R}$ & $\mathrm{R}$ & $\mathrm{R}$ & $\mathrm{R}$ & 30 & 28 & $\mathrm{R}$ & $\mathrm{R}$ & $\mathrm{R}$ & 24 & 20 & 14 \\
\hline & 8 & G4 & $\mathrm{R}$ & $\mathrm{R}$ & $\mathrm{R}$ & $\mathrm{R}$ & 20 & 20 & 22 & $\mathrm{R}$ & $\mathrm{R}$ & 14 & 14 & $\mathrm{R}$ \\
\hline & 9 & G3 & $\mathrm{R}$ & 18 & $\mathrm{R}$ & $\mathrm{R}$ & 26 & 24 & $\mathrm{R}$ & $\mathrm{R}$ & $\mathrm{R}$ & 20 & 28 & $\mathrm{R}$ \\
\hline & 10 & F5 & $\mathrm{R}$ & 14 & $\mathrm{R}$ & $\mathrm{R}$ & 20 & 24 & 16 & $\mathrm{R}$ & $\mathrm{R}$ & $\mathrm{R}$ & 20 & $\mathrm{R}$ \\
\hline \multirow[t]{9}{*}{ Escherichia coli } & 1 & A3 & $\mathrm{R}$ & $\mathrm{R}$ & 20 & $\mathrm{R}$ & 30 & 26 & 14 & $\mathrm{R}$ & 12 & 18 & 22 & 18 \\
\hline & 2 & $\mathrm{~F} 1$ & $\mathrm{R}$ & $\mathrm{R}$ & $\mathrm{R}$ & 10 & 24 & 22 & 26 & $\mathrm{R}$ & $\mathrm{R}$ & 20 & 28 & $\mathrm{R}$ \\
\hline & 3 & F10 & $\mathrm{R}$ & 16 & $\mathrm{R}$ & $\mathrm{R}$ & 16 & 12 & 26 & $\mathrm{R}$ & $\mathrm{R}$ & 20 & 24 & 16 \\
\hline & 4 & G4 & $\mathrm{R}$ & 14 & 20 & $\mathrm{R}$ & 28 & 16 & 16 & $\mathrm{R}$ & $\mathrm{R}$ & 22 & 18 & 16 \\
\hline & 5 & G3 & 14 & 12 & $\mathrm{R}$ & $\mathrm{R}$ & 30 & 22 & 20 & $\mathrm{R}$ & $\mathrm{R}$ & 18 & 14 & 12 \\
\hline & 6 & E9 & $\mathrm{R}$ & 14 & 12 & $\mathrm{R}$ & 14 & 22 & 18 & $\mathrm{R}$ & $\mathrm{R}$ & $\mathrm{R}$ & 16 & 20 \\
\hline & 7 & A4 & $\mathrm{R}$ & 18 & $\mathrm{R}$ & $\mathrm{R}$ & 14 & 18 & $\mathrm{R}$ & $\mathrm{R}$ & $\mathrm{R}$ & $\mathrm{R}$ & 20 & $\mathrm{R}$ \\
\hline & 8 & $\mathrm{E} 4$ & $\mathrm{R}$ & 10 & $\mathrm{R}$ & 14 & $\mathrm{R}$ & $\mathrm{R}$ & $\mathrm{R}$ & $\mathrm{R}$ & $\mathrm{R}$ & $\mathrm{R}$ & 16 & $\mathrm{R}$ \\
\hline & 9 & F8 & $\mathrm{R}$ & 12 & $\mathrm{R}$ & $\mathrm{R}$ & 24 & 24 & $\mathrm{R}$ & $\mathrm{R}$ & $\mathrm{R}$ & $\mathrm{R}$ & 24 & 12 \\
\hline \multirow[t]{10}{*}{ Proteus spp } & 1 & E6 & $\mathrm{R}$ & 18 & $\mathrm{R}$ & $\mathrm{R}$ & 22 & 14 & $\mathrm{R}$ & $\mathrm{R}$ & $\mathrm{R}$ & 12 & 22 & 16 \\
\hline & 2 & G10 & 20 & 28 & 12 & $\mathrm{R}$ & 30 & 24 & 24 & 14 & 10 & 28 & 26 & 18 \\
\hline & 3 & E2 & $\mathrm{R}$ & 20 & 12 & $\mathrm{R}$ & 28 & 26 & 22 & $\mathrm{R}$ & $\mathrm{R}$ & 32 & 26 & 20 \\
\hline & 4 & F2 & 14 & $\mathrm{R}$ & $\mathrm{R}$ & $\mathrm{R}$ & 16 & 12 & $\mathrm{R}$ & $\mathrm{R}$ & $\mathrm{R}$ & $\mathrm{R}$ & 22 & 20 \\
\hline & 5 & F6 & 12 & 12 & $\mathrm{R}$ & $\mathrm{R}$ & 28 & $\mathrm{R}$ & 14 & 16 & $\mathrm{R}$ & 10 & $\mathrm{R}$ & 14 \\
\hline & 6 & E1 & $\mathrm{R}$ & 18 & 22 & $\mathrm{R}$ & 20 & 14 & $\mathrm{R}$ & $\mathrm{R}$ & $\mathrm{R}$ & 20 & 20 & 22 \\
\hline & 7 & E8 & $\mathrm{R}$ & 20 & $\mathrm{R}$ & $\mathrm{R}$ & 20 & $\mathrm{R}$ & 12 & $\mathrm{R}$ & $\mathrm{R}$ & $\mathrm{R}$ & 24 & 20 \\
\hline & 8 & A5 & $\mathrm{R}$ & 12 & $\mathrm{R}$ & 12 & 32 & 14 & $\mathrm{R}$ & $\mathrm{R}$ & $\mathrm{R}$ & $\mathrm{R}$ & 24 & 22 \\
\hline & 9 & G9 & $\mathrm{R}$ & 12 & $\mathrm{R}$ & 12 & 28 & 20 & $\mathrm{R}$ & $\mathrm{R}$ & $\mathrm{R}$ & 14 & 20 & 20 \\
\hline & 10 & A2 & $\mathrm{R}$ & 12 & $\mathrm{R}$ & $\mathrm{R}$ & 28 & 20 & 14 & $\mathrm{R}$ & $\mathrm{R}$ & $\mathrm{R}$ & 14 & 20 \\
\hline
\end{tabular}

Table 5: Antibiotic Susceptibility Tests using standard discs showing zones of inhibition for fifty selected isolates.

KEY: VA - VANCOMYCIN 30ug; C - CHLORAMPHENICOL 30ug; SXT - SULPHAMETHAZOLE/TRIMETHORPRIM 25ug; CAZ - CEFTAZIDIME 10ug; IPM - IMIPENEM 10UG; GN - GENTAMICIN 30UG; F - NITROFURANTOIN 300UG; TE - TETRACYCLINE 30UG; CTX CEFTAXIME 30UG; AMC - AMOXICILLIN/CLAVULANIC ACID 30UG; OFX - OFLOXAXIN 5UG; E - ERYTHROMYCIN 15ug.

\section{Discussions and Conclusions}

Discussion

ATMs are social devices simple enough to be used by people from different socioeconomic class and hygiene status. The presence of microorganisms in public places has always been of concern due to the mode of transmission, which is usually through the hand. Most of the microorganisms are usually spread through the contaminated fingers/hands touching these surfaces, later transfer- ring the microorganisms to the unsuspecting individual who uses the device after contamination. Epidemiological studies have confirmed the role of contaminated surfaces in the spread of infectious diseases [1-3]. The present study shows that the Automated Teller Machine, which is present in all the local government areas visited were contaminated with different microorganisms with Staph aureus being the most prevalent bacteria present on the ATMs while Pseudomonas was the least prevalent. 


\begin{tabular}{|c|c|c|c|c|c|c|c|}
\hline \multirow{3}{*}{$\begin{array}{l}\text { Isolate ID } \\
\text { Staph aureus }\end{array}$} & \multirow{3}{*}{$\begin{array}{c}\text { Dettol } \\
\text { S/N }\end{array}$} & \multirow{3}{*}{$\begin{array}{l}\text { Savlon } \\
\text { ID }\end{array}$} & \multicolumn{5}{|c|}{ Diameter of zone of inhibition } \\
\hline & & & \multirow[t]{2}{*}{ JIK } & \multirow{2}{*}{$\begin{array}{l}\text { Distilled water } \\
\text { (-VE control) }\end{array}$} & \multirow{2}{*}{$\begin{array}{l}\text { Gentamicin } \\
\text { (+VE control) }\end{array}$} & & \\
\hline & & & & & & & \\
\hline & 1 & E1 & 20 & 28 & 20 & - & 16 \\
\hline & 2 & E2 & 16 & 28 & 20 & - & 16 \\
\hline & 3 & E9 & 18 & 30 & 20 & - & 14 \\
\hline & 4 & E5 & 20 & 28 & 18 & - & 16 \\
\hline & 5 & E8 & 22 & 24 & 20 & - & 18 \\
\hline & 6 & G10 & 22 & 26 & 22 & - & 16 \\
\hline & 7 & E7 & 20 & 22 & 20 & - & 14 \\
\hline & 8 & G9 & 22 & 26 & 22 & - & 14 \\
\hline & 9 & F10 & 20 & 28 & 20 & - & 16 \\
\hline & 10 & $\mathrm{~F} 2$ & 20 & 30 & 20 & - & 14 \\
\hline Pseudomonas & 1 & D1 & 18 & 28 & 20 & - & 20 \\
\hline aeruginosa & 2 & E4 & 12 & 20 & 18 & - & 26 \\
\hline & 3 & $\mathrm{~F} 4$ & 22 & 26 & 22 & $\mathrm{R}$ & 24 \\
\hline & 4 & D2 & 18 & 28 & 20 & - & 14 \\
\hline & 5 & $\mathrm{~A} 4$ & 20 & 26 & 20 & - & 16 \\
\hline & 6 & B4 & 18 & 24 & 20 & - & 18 \\
\hline & 7 & E6 & 20 & 28 & 18 & - & 14 \\
\hline & 8 & E5 & 22 & 22 & 20 & - & 18 \\
\hline & 9 & $\mathrm{C} 8$ & 18 & 20 & 18 & - & 18 \\
\hline & 10 & D10 & 20 & 22 & 20 & - & 16 \\
\hline Streptococcus spp & 1 & G1 & 20 & 22 & 16 & $\mathrm{R}$ & 20 \\
\hline & 2 & E7 & 28 & 36 & 22 & $\mathrm{R}$ & 26 \\
\hline & 3 & H3 & - & 16 & 18 & $\mathrm{R}$ & 24 \\
\hline & 4 & E7 & 24 & 20 & 20 & $\mathrm{R}$ & 20 \\
\hline & 5 & $\mathrm{~F} 2$ & 20 & 22 & 18 & $\mathrm{R}$ & 14 \\
\hline & 6 & F5 & 24 & 24 & 16 & $\mathrm{R}$ & 16 \\
\hline & 7 & H5 & 28 & 20 & 18 & $\mathrm{R}$ & 16 \\
\hline & 8 & $\mathrm{~F} 1$ & 22 & 26 & 16 & - & 16 \\
\hline & 9 & G4 & 20 & 30 & 20 & - & 14 \\
\hline & 10 & G3 & 18 & 28 & 18 & - & 18 \\
\hline Escherichia coli & 1 & A4 & 12 & 22 & 14 & - & 22 \\
\hline & 2 & F3 & 20 & 38 & 14 & - & 18 \\
\hline & 3 & G3 & 26 & 28 & 26 & - & 20 \\
\hline & 4 & $\mathrm{~F} 1$ & 22 & 30 & 20 & - & 18 \\
\hline & 5 & F10 & 18 & 32 & 18 & - & 14 \\
\hline & 6 & G4 & 18 & 28 & 22 & - & 16 \\
\hline & 7 & E9 & 22 & 26 & 20 & - & 14 \\
\hline & 8 & E4 & 18 & 30 & 18 & - & 16 \\
\hline & 9 & F8 & 16 & 28 & 18 & - & 14 \\
\hline & 10 & F1 & 22 & 24 & 20 & - & 14 \\
\hline
\end{tabular}




\begin{tabular}{|c|c|c|c|c|c|c|c|}
\hline \multirow[t]{10}{*}{ Proteus spp } & 1 & $\mathrm{~A} 2$ & 22 & 30 & 20 & - & 20 \\
\hline & 2 & E8 & 22 & 24 & 20 & - & 22 \\
\hline & 3 & A5 & 22 & 38 & 32 & - & 26 \\
\hline & 4 & G9 & 22 & & & & \\
\hline & 5 & E1 & 20 & 30 & 20 & - & 18 \\
\hline & 6 & F6 & 18 & 24 & 16 & - & 14 \\
\hline & 7 & $\mathrm{~F} 2$ & 20 & 28 & 18 & - & 14 \\
\hline & 8 & E2 & 16 & 24 & 20 & - & 18 \\
\hline & 9 & G10 & 20 & 28 & 22 & - & 16 \\
\hline & 10 & E6 & 18 & 30 & 26 & - & 12 \\
\hline
\end{tabular}

Table 6: Susceptibility Tests using commercial disinfectants showing zones of inhibition for fifty selected isolates.

\section{KEY: VA - VANCOMYCIN 30ug; C - CHLORAMPHENICOL 30ug; SXT SULPHAMETHAZOLE/TRIMETHORPRIM 25ug; CAZ - CEFTAZI- DIME 10ug; IPM - IMIPENEM 10UG; GN - GENTAMICIN 30UG; F-NITROFURANTOIN 300UG; TE - TETRACYCLINE 30UG; CTX - CEFTAXIME 30UG; AMC - AMOXICILLIN/CLAVULANIC ACID 30UG; OFX - OFLOXAXIN 5UG; E - ERYTHROMYCIN $15 U G$.}

Though, microorganisms that could be pathogenic were found on some of the ATMs, some studies showed that they are unlikely to cause infections except in immunocompromised individuals [1]. Another study showed the presence of Methicillin-resistant Staph aureus (MRSA) and Escherichia coli on some ATMs [2]. In another study in which 92 swabs were collected, Klebsiella was found on $42.5 \%$, Pseudomonas aeruginosa on $15 \%$ and E. coli on $10 \%$. Over eighty percent of the Klebsiella were Extended Spectrum Beta Lactamase (ESBL) producers and $40 \%$ were resistant to methicillin which is a source of public health concern.

In the preset study, it was obvious that the different bacteria had various resistant/sensitivity profile to the antibiotics used. Staph aureus was largely resistant to the common antibiotics and sensitive to the more expensive and not so commonly used antibiotics. Pseudomonas aeruginosa, which is mostly implicated in nosocomial infections, was virtually resistant to almost all the antibiotics including the fluoroquinolones. Gentamicin and Imipenem were the only one the microorganism had some measure of sensitivity. Streptococcus spp known to be responsible for most upper respiratory tract infection was found to be largely resistant to almost all the antibiotics except imipenem and gentamicin. E. coli and Proteus species had similar antibiogram profile as Streptococcus spp.

Interestingly, all the bacteria were sensitive to the commercially available disinfectants suggesting that the use of these disinfectants by contaminated individuals in the form of hand cleaning may reduce the spread. Also, regular disinfection of the ATMs with the commercially available disinfectants will reduce the spread of the bacteria among users of the ATM [10-27].

\section{Conclusion}

Automated Teller Machines (ATM) have a role in the transmission of microorganisms. In this study, Staphylococcus aureus, a normal hand commensal was the commonly isolated. Others, Streptococcus spp is implicated in upper respiratory tract infections, and Escherichia coli, a coliform, implying poor toilet habits of some of ATM users. The antibiogram of the isolates showed imipenem to be the most effective, and ceftazidime to be the least effective. The isolates were susceptible to the commercially available disinfectants tested.

\section{Acknowledgement}

I wish to acknowledge the efforts of my parents for their support in giving me a good education. I want to sincerely appreciate my supervisor, (Mrs) Durowaiye Mojirayo for supervising my dissertation, especially for the encouragement to put in my best in my dissertation and project work.

I also want to appreciate the Dean, Faculty of Pharmacy, University of Ibadan, Professor C.P. Babalola, for her support and encouragement. I also want to say thanks to all the members of staff, Department of Pharmaceutical Microbiology especially Mr Sunday Makinde, for their support in the course of my project work.

I want to specially appreciate Prof Titilayo Fakeye and Dr Abimbola Aiku both of University of Ibadan for the kindness, love as well emotional and spiritual support in the five years I spent in University of Ibadan in search of the golden fleece of bachelor's degree in pharmacy. 


\section{Recommendations}

Users of the ATMs should be encouraged to disinfect their hands after using the interface to reduce the microbial loads on their hands which in turn reduces the risk of hand-to-hand, handto-object-hand transmission. Also, the banks should be encouraged to disinfect the machines at least twice daily as it has been shown that pathogens can survive on formites for months.

\section{Appendix I}

Laboratory chemicals and reagents

The composition and preparation of the media used are as follows:

Culture Medium: Nutrient agar (Lab $\mathbf{M}^{\circledR}$ )

\begin{tabular}{|c|c|}
\hline Formula & Gram/Litre \\
\hline Peptone & 5.0 \\
\hline Beef extract & 3.0 \\
\hline Sodium Chloride & 8.0 \\
\hline Agar No 2 & 12.0 \\
\hline $\mathrm{pH}$ & $7.3 \pm 0.2$ \\
\hline
\end{tabular}

Table a

\section{Preparation}

The required weights equivalents to 28grams per litre was dispensed in distilled water, allowed to soak for 10 minutes, swirled, then sterilized by autoclaving for 15 minutes at $121^{\circ} \mathrm{C}$ and cooled before pouring into petri dishes.

Culture Medium: Nutrient Broth (Lab $\mathbf{M}^{\circledR}$ )

\begin{tabular}{|c|c|}
\hline Formula & Gram/Litre \\
\hline Peptone & 5.0 \\
\hline Beef extract & 1.5 \\
\hline Sodium Chloride & 5.0 \\
\hline Yeast Extracts & 1.5 \\
\hline $\mathrm{pH}$ & $7.4 \pm 0.2$ \\
\hline
\end{tabular}

Table b

\section{Preparation}

The required weight equivalent to 13 grams per litre was dispensed in distilled water and mixed properly to dissolve. It was then sterilized by autoclaving for 15 minutes at $121^{\circ} \mathrm{C}$ and cooled.

Culture Medium: Mueller-Hinton Agar (SRL ${ }^{\circledR}$ )

\begin{tabular}{|c|c|}
\hline Formula & Gram/Litre \\
\hline Beef dehydrated infusion & 300.0 \\
\hline Cassein hydrolysate & 17.5 \\
\hline Starch & 1.5 \\
\hline Agar & 17.0 \\
\hline $\mathrm{pH}$ & $7.3 \pm 0.1$ \\
\hline
\end{tabular}

Table c

\section{Preparation}

The required weight equivalent to 38grams per litre was dispensed in distilled water and mixed properly to dissolve. It was then sterilized by autoclaving for 15 minutes at $121^{\circ} \mathrm{C}$ and cooled.

Culture Medium: Eosin Methylene Blue Agar (Lab $\mathbf{M}^{\circledR}$ )

\begin{tabular}{|c|c|}
\hline Formula & Gram/Litre \\
\hline Balanced Peptone No1 & 10.0 \\
\hline Lactose & 10.0 \\
\hline Dipotassium dihydrogen phosphate & 0.7 \\
\hline Potassium dihydrogen phosphate & 1.3 \\
\hline Eosin Yellow & 0.4 \\
\hline Methylene Blue & 0.065 \\
\hline Agar No 2 & 15.0 \\
\hline
\end{tabular}

Table d

\section{Preparation}

The required weight equivalent to 37.5 grams per Litre was dispensed in distilled water and allowed to soak for 10 minutes, swirled, then sterilized by autoclaving for 15 minutes at $121^{\circ} \mathrm{C}$, and allowed to cool before pouring into Petri dishes.

Culture Medium: MacConkey agar (Lab M ${ }^{\circledR}$ )

\begin{tabular}{|c|c|}
\hline Formula & Gram/Litre \\
\hline Peptone & 17.0 \\
\hline Lactone & 10.0 \\
\hline Sodium Chloride & 5.0 \\
\hline Proteose Peptone & 3.0 \\
\hline Bile Salts & 1.5 \\
\hline Neutral Red & 0.03 \\
\hline Crystal Violet & 0.001 \\
\hline Agar & 13.5 \\
\hline pH & $7.1 \pm 0.2$ \\
\hline
\end{tabular}

Table e 


\section{Preparation}

The required weight equivalent to 48.5 grams per Litre was dispensed in distilled water, allowed to soak for 10 minutes, swirled, then sterilized by autoclaving for 15 minutes at $121^{\circ} \mathrm{C}$ and cooled before pouring into petri dishes.

\section{Culture Medium: Peptone Water (Lab $\mathbf{M}^{\circledR}$ )}

\begin{tabular}{|c|c|}
\hline Formula & Gram/Litre \\
\hline Peptone & 5.0 \\
\hline Tryptone & 5.0 \\
\hline Sodium Chloride & 5.0 \\
\hline
\end{tabular}

Table f

\section{Preparation}

The required weight equivalent to $15 \mathrm{~g} /$ Litre was dispensed in distilled water, swirled to mix and dispensed in final containers, then sterilized by autoclaving for 15 minutes at $121^{\circ} \mathrm{C}$.

Kovacs Reagent (containing isoamyl alcohol, para-dimethylaminobenzaldehyde, concentrated hydrochloric acid).

Sterile distilled water.

\section{Bibliography}

1. Tekerekoğlu M S., et al. "Bacteria found on banks automated teller machines (ATMs)". African Journal of Microbiology Research 7.16 (2013): 1619-1621.

2. Nagajothi J., et al. "Study of Prevalence of Microbial Contamination with its Antibiotic Resistance Pattern in Automated Teller Machine in and around Puducherry, India". Journal of Earth Environment and Health Sciences 1.1 (2015): 27-31.

3. Tagoe D N A and Kumi-Ansah F. "Computer keyboard and mice: Potential sources of disease transmission and infections". The Internet Journal of Public Health 1.2 (2011).

4. Dogan M., et al. "Investigation of microbial colonization of computer keyboards used inside and outside hospital environments". Mikrobiyoloji Bülteni 42.2 (2008): 331-336.

5. Brock Biology of Microorganisms 11th edition. Edited by Michael T. Madigan and John M. Martiniko, 2006 Prentis Hall, New Jersey, USA (2005).

6. Becker K., et al. "Coagulase-negative staphylococci". Clinical Microbiology Reviews 27.4 (2014): 870-926.

7. Singleton P. "Bacteria in biology, biotechnology and medicine 5th edition”. Wiley, Hoboken, (1999): 444-454.
8. Olaniyi A A., "Essential medicinal chemistry". Shaneson CI Limited (1989).

9. Gorman S and Scott E. "Chemical Disinfectants, Antiseptics and Preservatives, in Hugo and Russell's: Pharmaceutical Microbiology, Seventh Edition (eds S. P. Denyer, N. A. Hodges and S. P. Gorman), Blackwell Science Ltd, Oxford, UK (2004).

10. Akinjogunla OJ., et al. "Phenotypic Detection of Virulence Markers, Antibiotic and Disinfectant Susceptibility of Bacterial Isolates from Automated Teller Machine Keypads, Computer Keyboards and Mice in Uyo, Nigeria". British Biotechnology Journal 15.3 1-15.

11. Bagley ST. "Habitat Association of Klebsiella Species". Infection Control 6.2 (1985): 52-58.

12. Clinical and Laboratory Standards Institute Performance Standards for Antimicrobial Susceptibility Testing; Sixteenth Informational Supplement. CLSI Document M100-S16. CLSI, Wayne, PA, US. (2012).

13. Dongyou L., "Molecular Detection of Human Bacterial Pathogens”. CRC Press. Taylor and Francis Group (2011).

14. Itah AY and Essien JP. "Growth Profile and Hydrocarbonoclastic Potential of Microorganisms Isolated from Tarballs in the Bight of Bonny, Nigeria". World Journal of Microbiology and Biotechnology 21.6-7 (2005): 1317-1322.

15. Jansen A and Kielstein JT. "The new face of enterohaemorrhagic Escherichia coli infections". Eurosurveillance 16.25 (2001): 19898.

16. Joshaline CM., et al. "Automated Teller Machine (ATM)-A "pathogen city"-A surveillance report from locations in and around Madurai city, Tamil Nadu, India". International Journal of Public Health Science (IJPHS) 3.1 (2014): 51-56.

17. Larson EL., "Warned, but not well-armed: preventing viral upper respiratory infections in households". Public Health Nursing 24.1 (2006): 48-59.

18. Makinde A E I., "Bacteriological Assessment of Some Automated Teller Machine (ATM) Keypads In Ilorin Metropolis". Ilorin Journal of Science 1.2 (2014).

19. Mathai E., et al. "Prevention and control of health-care associated infections through improved hand hygiene". Indian Journal of Medical Microbiology 28.2 (2010): 100-106.

20. Nachimuthu R., et al. "Prevalence of multi drug resistant strains on touch screen of automated teller machine". Asian Journal of Pharmaceutical and Clinical Research 8.2 (2015): 409-411. 
21. Nwankwo EO and Offiah JC. "Bacterial Contamination of User Interface of Automated Teller Machines (ATM) of Various Banks in Umuahia Metropolis, Abia State, Nigeria". hypothesis 4.56 .

22. Nworie 0., et al. "Antibiogram of bacteria isolated from automated teller machines within abakaliki metropolis". American Journal of Infectious Diseases 8.4 (2012): 168-174.

23. Onuoha S C and Fatokun K. "Bacterial Contamination and Public Health Risk Associated with the Use of Banks' Automated Teller Machines (Atms) in Ebonyi State, Nigeria". American Journal of Public Health Research 2.2 (2014) 46-50.

24. Saroja V., et al. "Enumeration and Characterisation of Coliforms from Automated Teller Machine (ATM) Centers in Urban Areas". (2013).

25. World Health Organization (WHO) "Transmission dynamics and impact of pandemic influenza A (H1N1) 2009 virus". The Weekly Epidemiological Record 84.46 (2009): 481-484.

26. Zhang M., et al. "Characterization of staphylococci contaminating automated teller machines in Hong Kong". Epidemiology and infection 140.8 (2012): 1366-1371.

27. Boost M., et al. "Staphylococcus aureus: what are the levels of contamination of common-access environmental surfaces?". Infection Control and Hospital Epidemiology 29.2 (2008): 194196.

\section{Volume 3 Issue 6 June 2019}

(C) All rights are reserved by Adedeji Bolutife Adedoyin. 